CORRECTION

\title{
Correction: Longitudinal microbiome profiling reveals impermanence of probiotic bacteria in domestic pigeons
}

\section{Kirsten Grond, Julie M. Perreau, Wesley T. Loo, A. James Spring, Colleen M. Cavanaugh,} Sarah M. Hird

The last three authors, A. James Spring, Colleen M. Cavanaugh, and Sarah M. Hird, should not have been attributed equal contribution to this work. Instead, Colleen M. Cavanaugh (cavanaug@fas.harvard.edu) and Sarah M. Hird (sarah.hird@uconn.edu) should be listed as corresponding authors.

\section{Reference}

1. Grond K, Perreau JM, Loo WT, Spring AJ, Cavanaugh CM, Hird SM (2019) Longitudinal microbiome profiling reveals impermanence of probiotic bacteria in domestic pigeons. PLoS ONE 14(6): e0217804. https://doi.org/10.1371/journal.pone.0217804 PMID: 31206549

G open access

Citation: Grond K, Perreau JM, Loo WT, Spring AJ, Cavanaugh CM, Hird SM (2019) Correction: Longitudinal microbiome profiling reveals impermanence of probiotic bacteria in domestic pigeons. PLoS ONE 14(7): e0220347. https://doi. org/10.1371/journal.pone.0220347

Published: July 23, 2019

Copyright: @ 2019 Grond et al. This is an open access article distributed under the terms of the Creative Commons Attribution License, which permits unrestricted use, distribution, and reproduction in any medium, provided the original author and source are credited. 